JASNA ŠEGO

\title{
LIK SVEĆENIKA U NOVAKOVU ROMANU POSLJEDNJI STIPANČIĆI
}

Jasna Šego

Sveučilište u Slavonskom Brodu

Odjel društveno-humanističkih znanosti

Učiteljski studij

Gundulićeva 20

HR 35000 Slavonski Brod

jsego@unisb.hr
UDK: 82.163.42.09Novak, V. Izvorni znanstveni članak

Ur.: 2021-08-22

U članku se istražuje lik svećenika u Novakovu romanu Posljednji Stipančići (1899.). Izdvajaju se biskup Ćolić i kanonik Vukasović. Prvi se javlja u Valpurginu snu koji je motivira na pripovijedanje (Luciji) o epizodi u kojoj su ga zlobnici i zavidnici oklevetali i optužili da je zaveo djevojku iz ugledne obitelji, ali i o biskupovoj uspješnoj samoobrani. Drugi je lik kanonik Vukasović kao moralni i duhovni narodni autoritet, domoljub i borac za opće narodno dobro.

Zaključuje se da se oba lika uklapaju u standarde koje je promicao Glasnik/Viesnik Đakovačke i Sriemske biskupije (a koji su vrijedili i koji su se mogli primijeniti u cijeloj Hrvatskoj) iz prve faze svojega izlaženja te da su u skladu sa življenim idealima biskupa Mirka Ožegovića u stvarnome svijetu tadašnjega Senja. domoljub

Ključne riječi: svećenik, biskup Ćolić, kanonik Vukasović, moralni i duhovni uzor,

Uvod: lik svećenika kao intrigirajuća tema u stvarnom i mogućem svijetu

Lik je svećenika kao Božjega čovjeka, posrednika između Boga i ljudi, uzorna i smjerna, ali i kao "čovjeka od krvi i mesa" zanimljiva i intrigirajuća tema svakodnevnoga života i privlačna tema kako svjetske tako i hrvatske književnosti. Tko su zapravo svećenici? Koja je bit njihova poziva? Koja je njihova uloga u svijetu? "Posrednici između božanst(a)va i ljudi i ljudi i božanst(a)va u religiji su svećenici. Bit svećeničkog poziva je, dakle, u tome da on moli za ljude, prinosi žrtve u njihovo ime i da, istodobno, prenosi poruke božanst(a)va ljudima, njegove odluke, želje i planove (s) njima."1 Njegovo je zvanje "multidimenzionalno

\footnotetext{
${ }^{1}$ S. TADIĆ, 1993, 8.
} 
i slojevito", a kao religijski je vođa "ponajprije onaj koji prinosi žrtvu (̌̌rtvovatelj), 'privodi duše Bogu' (dušobrižnik), ima ulogu moralnog učitelja i propovjednika, štoviše i ponekad i moralnog arbitra, savjetnika u frustracijskim i kriznim situacijama 'ovaca svog stada', terapeuta itd."2 Takva uloga znači i povlašteni pristup privatnom području života njegovih vjernika. Valja istaknuti transcendentalnu i moralnu dimenziju svećenikova života: "Vjeruje se, naime, da je svećenik u neposrednom kontaktu s transcendentnom, onostranom moću te da on tu moć razumije bolje od običnog vjernika svjetovnjaka. Također vlada mišljenje da on bolje razumije etičko-moralnu sferu života negoli obični vjernici, za koju je svaka religija, per se et proxime, zainteresirana." ${ }^{3}$ Posvećen je božanstvu i u službi je svetoga i Crkve, s jedne strane povijesne i vremenite, a s druge strane transcendentne, eshatološke.

Svećenik je uvijek pod velikim povećalom javnosti-onih koji ga u principu podržavaju, koji su mu skloni, ali i onih drugačijih mišljenja, stavova i pogleda na svijet. Svećenik, dakle, kako u stvarnom tako i u mogućem svijetu - uvijek privlači pozornost. Svojom ulogom i položajem na društvenoj ljestvici budi znatiželju, intrigira dobronamjernika i nedobronamjernika, vjernika, nevjernika i agnostika, ljude širokih vidika, ali i one koji gledaju na svijet uskogrudno $\mathrm{i}$ priznaju samo vlastitu istinu. Vjernici očekuju od svećenika da bude uzor, moralna vertikala, svjetlo i putokaz, savjetodavac i nadahnitelj, prijatelj i učitelj, da bude pozoran i strpljiv slušatelj, mudar i razborit životni usmjeritelj, pomagač u teškim životnim situacijama, ali i onaj koji svoju sreću rado dijeli s drugima i koji se raduje tuđoj sreći.

Nije lako biti svećenikom. Taj je poziv veoma zahtjevan. Svećenikove se pogrješke ne praštaju tek tako. Mnogi imaju posebne kriterije za procjenu svećenikova karaktera, mnogo strože od onih kojima se podvrgavaju tzv. obični ljudi. Svako vrijeme stavlja pred svećenika svoja očekivanja i zahtjeve. Neki od svećenika očekuju previše pa kad on ne dosegne očekivane standarde i ne ispuni očekivane zahtjeve, optužuju ga. Protivnici Crkve kao institucije skloni su kritiziranju, omalovažavanju i ponižavanju svećenika kao osoba, nerijetko prema njima iskazuju netrpeljivost te ne prežu ni od vrijeđanja. Brojnim su vjernicima, pak, svećenici uzori, svjetiljke na životnome putu, ljudi od povjerenja kojima mogu izreći svoje tjeskobe i boli, ali i tajne želje. Vjernici koji se pouzdaju u svećenike sigurni su da će ih Božji ljudi pozorno saslušati, utješiti, ohrabriti, savjetovati, usmjeriti, potaknuti na djelovanje. Nekima su svećenici rame za plakanje, oslonac, utočište, istinska poveznica s Bogom.

\footnotetext{
${ }^{2}$ S. TADIĆ, 1993, 8-9.

${ }^{3}$ S. TADIĆ, 1993, 9.
} 
I svećenik je zapravo samo čovjek; i on je grješan i slab, biće koje se neprestano gradi i usavršava. I on se suočava s tjeskobama i kušnjama, $s$ osamljenošću i nutarnjim borbama. Za svećeničko je zvanje potrebna hrabrost, odaziv na Božji poziv, duhovna spremnost i odgovornost. Svećenik je čovjek vjere, nade, ljubavi, radosti, odgovornosti. On okuplja, odgaja, pomaže drugima širiti vidike. Svećenik treba biti onaj koji osluškuje Božju riječ, koji razumije bližnjega, koji živi za Boga, Crkvu i ljude. Katolički svećenik živi u celibatu da bi bio bliže Kristu. Vezan je uz društveno-političku i kulturnu situaciju svojega društva i nerijetko intenzivno i plodno u njemu djeluje.

Lik je svećenika prisutan u brojnim djelima kako svjetske tako i hrvatske književnosti te kao istraživačka tema u znanosti o književnosti nudi puno potencijala. ${ }^{4}$

\section{Utjecaj društveno-političke situacije Novakova doba na njegovo stvaralaštvo}

Vjenceslav Novak (1859. - 1905.) bio je snažno zainteresiran za aktualna zbivanja svojega vremena, što se plodno odrazilo na njegovo stvaralaštvo. Gospodarske, socijalne, povijesne i političke prilike Khuenova doba (politička, gospodarska i kulturna porobljenost hrvatskoga naroda) snažno su utjecale na Novakove teme, motive, likove i poruke.

Opus "senjskoga Šenoe" i "hrvatskoga Balzaca" obuhvaća velik broj tema, problema i likova: osiromašivanje plemstva, obiteljsko propadanje, obespravljenost žena, nevolje ljudi s društvenoga ruba, pravdu i nepravdu, seljake, radnike i građane, siromahe, prosjake i beskućnike, umjetnike i đake, činovnike i svećenike itd.

Kritika je davno prepoznala tri Novakova temeljna tematska kruga: život rodnoga Senja i njegove okolice (tašti, propali patriciji, osiromašeni trgovci, nesnalaženje bogataških sinova u novim društveno-političkim i gospodarskim prilikama, sjećanja na nekadašnji ugled i sjaj, sirotinja, laskavci, poltroni, obespravljene žene, obični mali ljudi i sl.), Podgorje (priče o ljudima koji su se odali kriminalu, zločinu, prosjačenju, koji su doživjeli moralni krah, o lažnim slijepcima, bogaljima i beskućnicima), život grada i njegovih stanovnika (građana i malograđana, poluinteligenata, trgovaca i činovnika, obrtnika i slugu, učitelja i siromašnih đaka, birokrata i ljudi s društvenog dna, borba s bolešću,

${ }^{4}$ Sjetimo se npr. Augustinovih Ispovijesti, Boccacciova Decamerona, Šenoina Prijana Lovre, Novakovih Zapreka, Braće Karamazovih Dostojevskog, Selimovićeva romana Derviš $i$ smrt itd. 
siromaštvom, nepravdom i sl.), "a u tom relativno kratkom stvaralačkom vijeku prošao je Novak izrazitu i brzu stvaralačku evoluciju od Šenoina epigona do značajnoga prethodnika i vjesnika modernističkih stvaralačkih, tematskih i stilskih zaokupljenosti."5

U Novakovo je doba Hrvatska obilježena sukobom pripadnika tadašnjih vodećih političkih stranaka - pravaša i narodnjaka, političkim, gospodarskim i klasnim previranjima i promjenama što je utjecalo na svekoliko zaostajanje hrvatskoga naroda (a to je umnogome slabilo otpor vladajućem režimu). Hedervary se služio poznatim načelom "Zavadi pa vladaj!" pa je stranačke prvake i intelektualce slamao cenzurom, progonima, nasiljem, nazadovanjem u službi i sl.

Strani kapital prodire u Hrvatsku, tuđinci nemilosrdno iskorištavaju hrvatska prirodna bogatstva. Sitni posjednici i seoske zadruge propadaju, sela osiromašuju, a strani kapitalisti u osiromašenim seljanima nalaze jeftinu radnu snagu. Hrvatski su gradovi gospodarski slabi, sirotinja (uglavnom seoskoga podrijetla) je u gradovima mahom bez posla, živi bez temeljnih životnih uvjeta. Strani bankari i tvorničari ne žele zapošljavati neobrazovanu radnu snagu. Hrvatsko građanstvo gotovo da ne postoji. Pokušavajući preživjeti, sitno plemstvo prihvaća slabo plaćenu državnu službu, a krupno se plemstvo priklanja (da ne bi bilo potpuno marginalizirano) vladajućem režimu. Plemići, nekadašnji čuvari tradicije, nacionalne svijesti, domoljublja i ponosa, moraju se odreći uzvišenih ideala (katkad sanjaju o povratku "starih, dobrih vremena"). Teška gospodarska situacija i nezavidne društveno-političke okolnosti obeshrabruju duh malobrojne hrvatske inteligencije. Narod tone ne samo u gospodarsku nego i u duhovnu bijedu i malograđanštinu. Hrvatska postaje obespravljenom, rubnom mađarskom kolonijom i duhovnom provincijom.

U tome razdoblju propada i grad Senj. Nekada bogato gospodarsko, trgovačko i kulturno središte (sa snažnim vezama sa zaleđem i prekomorjem) i važna luka, postaje grad na margini. Do 1871. godine Senj je bio pod austrijskom vojnom upravom. Izgradnjom željezničke pruge do Rijeke, Rijeka postaje novim gospodarskim, trgovačkim, lučkim i prometnim središtem zbog kojega Senj gubi svoju važnost. Zbog uvođenja parobroda propadaju bogati senjski vlasnici jedrenjaka koji ne mogu dovoljno brzo slijediti ritam prometnih i trgovačkih tijekova koje nameću strani (uglavnom mađarski) kapitalisti, koji usmjeruju promet prema riječkoj luci. Senj, dakle slabi gospodarski, politički, kulturno i duhovno. Propadaju patriciji i trgovci, nekadašnji uglednici životare, uzaludno

${ }^{5}$ D. MERKLER, 1999, 23. 
pokušavajući sačuvati stari sjaj (žive tek u iluzijama, dozivaju u sjećanje slavnu prošlost, ali ne mogu se uspješno nositi s novim vremenima i doživljavaju krah). Svjedoče političkim borbama, zakulisnim igrama, poltronstvu, konformizmu pojavama koje koče razvoj hrvatskoga društva.

\section{Novakov promatrački dar u Posljednjim Stipančićima}

O Novakovu romanu Posljednji Stipančići pisalo se s različitih motrišta. Zahvaćene su brojne teme i motivi (propadanje senjskih patricija, društvenopolitički odnosi i gospodarske prilike u Senju tridesetih godina 19. st., obiteljsko propadanje, potraga za ljubavlju i srećom, društveno-političke promjene u Senju), analizirani su glavni likovi romana i sl.

Roman je tematski vezan uz senjski krug i Novakovo posljednje, zrelo stvaralačko razdoblje. To je socijalni, obiteljski, društveni, politički, regionalni roman (iako se neki obrađeni problemi mogu odnositi i na šire hrvatsko područje). Djelo počinje 1834., opisom završne etape životnoga puta majke Valpurge i njezine kćeri Lucije Stipančić. Sveznajući pripovjedač vraća se zatim u prošlost, prikazujući uzroke propasti nekada bogate i ugledne obitelji, društvene, gospodarske i političke odnose i turbulencije koje su utjecale na propadanje spomenute obitelji. U prvom je pak planu romana sudbina članova obitelji Stipančić, napose Lucije i Valpurge, a onda i Ante i Jurja Stipančića.

O Novakovu promatračkome daru, opsegu građe i širokoj slici života koju je taj pisac oblikovao, Antun Barac piše: "Novak je imao jak promatrački dar. Po svojim pripovijestima on je jedan od onih hrvatskih pisaca, koji su u svojim djelima obuhvatili najviše tipova i pojava iz našega života. Bogatstvom gradiva, što ga je u različitim spisima iznio, pripada među književnike, koji su nastojali unijeti u književnost sav hrvatski život svoga vremena, i po njegovim oblicima i po pitanjima, koja su njime pokretala. Možda bi mu se u tome pogledu moglo dati i prvo mjesto."6

Miroslav Šicel približuje nam Novakov način promatranja stvarnosti: "S književno-historijskog stajališta, Novak se od izrazitog regionaliste iz prve faze svog književnog rada razvio u pisca koji je ipak možda najrealnije gledao na cjelokupni hrvatski društveni život. Osim toga, on se najviše od svih hrvatskih realista služio teorijom realizma, sustavno promatrajući život i praveći bilješke koje je kasnije koristio u svojim djelima. No pri tom traženju autentičnog materijala Novak je često upadao u greške da samo fotografira pojedinosti." ${ }^{17}$

\footnotetext{
${ }^{6}$ A. BARAC, 1941, 274.

${ }^{7}$ M. ŠICEL, 1971, 95.
} 
Krešimir Nemec spominje društvenu dramu koja se zbiva u pozadini romana Posljednji Stipančići: "propadanje senjske pomorske trgovine, klasna i politička previranja, prodor ilirskih ideja. Nitko među hrvatskim realistima nije uspio tako uspješno i tako uvjerljivo povezati sociološke činjenice $s$ pojedinačnim ljudskim sudbinama kao što je to pošlo za rukom Vjenceslavu Novaku u Posljednjim Stipančićima."

Slobodan Prosperov Novak u prikazu stvaralaštva Vjenceslava Novaka dotiče i "senjsku" problematiku: "Najveći dio njegova opusa posvećen je rodnom Senju koji skučen podno Velebita, upravo u Novakovo doba ima iznimnu važnost u hrvatskoj političkoj geografiji. Nalazeći se do 1871. pod vojnom upravom, taj je grad u piščevo doba bio čvorište kompliciranih ekonomskih odnosa i s turskim istokom, a i s bečkim sjeverom i talijanskim jugom. Nije zato čudno da su dva senjska dječaka, Silvije Strahimir Kranjčević i Vjenceslav Novak, stekla najsnažniji socijalni sluh u tadašnjoj hrvatskoj književnosti. Senj je bio gradić zapušten, pa je to nekad ponosno uskočko gnijezdo sada bilo prepušteno samo sebi." ${ }^{19}$ Dubravko Jelčić ovako vrjednuje Stipančiće: "možda najbolji roman hrvatskog realizma, a nedvojbeno najzrelije Novakovo djelo, summa njegovih životnih pogleda i spisateljskog umijeća." ${ }^{10}$

Milivoj Solar dijeli Jelčićevo mišljenje te ga jasno i čvrsto potkrjepljuje: "Najuspjelijim djelom smatra se roman Posljednji Stipančići, koji na pozadini propadanja jedne senjske patricijske obitelji u širokom spektru razrađuje kako sudbine pojedinaca tako i procese osiromašivanja senjskoga gospodarstva i trgovine, politička zbivanja vezana s buđenjem nacionalne svijesti te pogubni utjecaj nekih privrednih i kulturnih zbivanja na raspad obitelji i na svijest njezinih članova. Zbog uspjele psihološke analize, osobito ženskih likova (Lucija Stipančić), prepletanja retrospektivnog autorskog pripovijedanja s unutarnjim monologom i umetnutim pismima, te uvjerljive analize društvenih procesa $u$ prostorno i vremenski određenoj radnji, roman zauzima visoko mjesto u hrvatskoj književnosti epohe realizma, a u njemu se čak naziru i osobine modernizma." ${ }^{11}$

\section{Svećenici u stvarnom i u mogućem svijetu}

Iako se u romanu Posljednji Stipančići pojavljuju likovi svećenika (doduše ne u glavnim ulogama), o njima se nije detaljnije pisalo. Već smo najavili da ćemo

\footnotetext{
${ }^{8}$ K. NEMEC, 1995, 232.

${ }^{9}$ S. PROSPEROV NOVAK, 2004, 130.

${ }^{10}$ D. JELČIĆ, 1997, 158.

${ }^{11}$ M. SOLAR, 2011, 333-334.
} 
u ovome članku istražiti dva lika svećenika u spomenutom Novakovu romanu: lik biskupa Ćolića i lik kanonika Vukasovića - u kojim se kontekstima pojavljuju, kako ih Novak prikazuje, koje mjesto na hijerarhijskoj ljestvici zauzimaju, koja je njihova uloga u društveno-političkom i duhovnom životu, kako se odnose prema svojim vjernicima, svojemu narodu, povijesti, tradiciji, vrijednostima. Tako ćemo dobiti širu sliku društvenih zbivanja u Senju i Hrvatskoj te jasniji pogled na ulogu svećenika u hrvatskome narodu Novakova vremena.

Kada se govori o prikazu lika svećenika u stvarnome životu, zanimljivo je spomenuti članak Đure Hranića Lik svećenika u Glasniku/Viesniku Đakovačke $i$ Sriemske biskupije, koji piše o liku svećenika tijekom 125-godišnjice povijesti toga časopisa. Autor toga članka djelovanje Glasnika/Viesnika prati tijekom triju razdoblja (prema sadržajnim i tematskim specifičnostima): od početka izlaženja časopisa 1873. do Prvoga svjetskog rata (1914. - 1918.) i stvaranja nove države, Kraljevine Srba, Hrvata i Slovenaca kojoj je pripadao i teritorij Đakovačke i Srijemske biskupije), zatim od Prvoga svjetskoga rata do Drugoga vatikanskog koncila (1962. - 1965.) i napokon od Drugoga vatikanskog koncila do danas. U svakom od triju navedenih razdoblja autor zamjećuje da se svećenikov lik odlikuje određenim (specifičnim) značajkama. Ambicija je spomenutoga Glasnika od svojega utemeljenja bila obrazovanje i trajna svećenička izgradnja, ne samo onih u Đakovačkoj i Srijemskoj biskupiji nego i u drugim biskupijama u kojima se govorilo hrvatskim jezikom (zato se i usuđujemo spomenute proklamirane svećenikove osobine povezati s mogućim svijetom Posljednjih Stipančića i likovima svećenika koji se u njima pojavljuju).

Slika svećenika je u Glasniku/Viesniku ovisila o teološko-ekleziološkim naglascima određenoga vremena, o događajima, procesima i duhovnome ozračju u samoj crkvi, o tadašnjim društveno-političkim prilikama. O atmosferi u crkvenome i društvenome životu ovisio je i izbor tema, stil i osobine svećenikova lika koje su se prikazivale u Glasniku/Viesniku.

U ovome ćemo se članku usmjeriti na značajke svećenikova lika od početka izlaženja Glasnika/ Viesnika do Prvoga svjetskoga rata, dakle na prvu fazu njegova izlaženja (tridesetak godina nakon zbivanja u Posljednjim Stipančićima) kada se svećenika promatra kao čovjeka svestranoga obrazovanja (temeljite teološke i opće humanističke naobrazbe, poznavatelja povijesti, filozofije i stranih jezika, da bi mogao naviještati Božju riječ, ispovijedati, tješiti, propovijedati, savjetovati), evangelizatora, rodoljuba, prosvjetitelja, kulturnog radnika, čovjeka Crkve, duhovnosti i vjere, molitelja, marljiva čovjeka, društveno-političkoga djelatnika, župnoga administratora i upravitelja crkvene baštine. ${ }^{12}$ Također ćemo panoramski prikazati djelovanje senjskoga biskupa 
Mirka Ožegovića, za čijega se službovanja događa velik dio radnje Posljednjih Stipančića., i koji je svojom osobnošću utjelovio model svećenika svojega vremena. Izdvojene ćemo značajke pokušati povezati s osobinama odabranih likova svećenika u Posljednjim Stipančićima.

$\mathrm{Na}$ stranicama ovoga rada već smo istaknuli snagu Novakova zapažanja i pripovjedačkoga umijeća. O njegovu autentičnome prikazu svakodnevnoga života u Senju Dragomir Babić piše: "U Novakovu romanu Posljednji Stipančići kao na mozaičnoj plohi sve je sačinjeno od prividno trivijalnih pojedinosti, što zapravo predstavljaju pravi svakodnevni senjski život (Winter i Benetti kao negativni predstavnici Vojne uprave, prepričavanja senjske služavke Gertrude, Jurjevo krštenje, ritualni sjaj senjske aristokracije, opis vanjštine i strukture interijera Stipančićeve bogataške kuće, rodoljubno djelovanje senjskog kanonika Vukasovića i druge pojedinosti). Složenost političkih prilika u Senju i polet hrvatskoga narodnog preporoda dat je faktografskom preciznošću i logičnim tumačenjem prilika što su potresale cijeli grad Senj. Sa svake stranice romana čitatelj vidi Senj, a prema tim opisima ne može ostati ravnodušan ni povjesničar Senja, budući da Novak nevjerojatno živo i višeslojevito projicira totalitet senjske sudbine $u$ tom vremenu što ne može dočarati nikakva povijesna listina, kronika i bilo koji drugi povijesni dokument." ${ }^{13}$ Ipak, da bismo dobili potpuniju sliku svećeničkog djelovanja u mogućem svijetu, zaronit ćemo i u stvarnu senjsku povijest koja obuhvaća vrijeme u kojemu se odvija radnja Posljednjih Stipančića.

Usmjerimo li pozornost na povijest senjskoga srednjeg školstva, nalazimo podatak da je 1725. godine u Senju otvorena gimnazija (pod vodstvom pavlina). Nastavni je jezik u gimnaziji bio latinski, a trebali su je završiti svi svećenički kandidati. Pokušaj nametanja njemačkoga jezika u gimnaziji krajem 18. st. nije uspio (latinski je ostao nastavnim jezikom). Početkom 19. st. Senj je u sastavu Napoleonove Ilirije, a nakon odlaska Francuza ponovno je vraćen Vojnoj krajini. Godine 1806. u Senju je osnovan studij teologije, a 1808. filozofski licej. Godine 1820. senjska je gimnazija službeno zatvorena. Senjski biskup Mirko Ožegović za svojega ju je službovanja (1833. - 1869.) uspio ponovno otvoriti (1839.). Pravo je javnosti gimnazija dobila 1843. godine, a isto je pravo dobilo i filozofsko učilište ili licej godine 1845. (bila je to dvogodišnja škola koja je pripremala i osposobljavala učenike za upis na visoke škole i fakultete). Licej je pridružen senjskoj gimnaziji 1849. godine. Biskup je Ožegović 1857.

\footnotetext{
${ }^{12}$ Usp. Đ. HRANIĆ, 1998, 227-256.

${ }^{13}$ D. BABIĆ, 1996, 104.
} 
osnovao Zavod u kojemu su mogli boraviti pitomci. Omogućio je školovanje darovitim, ali siromašnim mladićima. Budući da u njegovoj Biskupiji nije bilo dovoljno svećenika i profesora, Franji Račkom omogućio je odlazak u Rim na usavršavanje. Biskup Ožegović proširio je kor senjske katedrale te je osnovao glazbeno društvo. Budući da je stari biskupijski dvor dotrajao i postao pretijesan, sagradio je, 1835. godine, novi. Neko je vrijeme bio upravitelj Glazbene akademije u Zagrebu. Bio je ugledan član Hrvatskoga sabora. Godine 1848. bio je na čelu poslanstva koje je dovelo Josipa Jelačića za hrvatskoga bana, nakon čega je u crkvi Svetoga Marka služio svečanu staroslavensku misu. Iste je godine (među prvim hrvatskim biskupima) u svoj ured uveo narodni jezik. Zalagao se za očuvanje hrvatskoga jezika te za njegovo podizanje na višu kulturnu razinu. Pisao je profesorima Bogoslovije u Senju da predaju teološku znanost na narodnom jeziku. Hvalio je Gajevu brigu za čistoću hrvatskoga jezika. Svećenike je poticao na uključivanje u prikupljanje narodnoga blaga za Gajeve Novine horvatzke te da ih redovito naručuju. ${ }^{14}$ Usput rečeno, za boravka u Senju Ivan Kukuljević je 1843. izjavio da "nigdje nije našao veće ljubavi k jeziku i hrvatskoj narodnosti... osobito svećeništva."15 Nakon pojave Ilirskoga pokreta u senjskoj je gimnaziji najzastupljeniji bio njemački jezik jer je Senj pripadao Vojnoj krajini, u kojoj je službeni jezik bio njemački. Ukidanjem Vojne krajine nastavni je jezik u gimnaziji postao hrvatski.

Biskup Mirko Ožegović bio je dobrotvor, domoljub, duhovno snažan čovjek koji je zahtijevao predan rad i disciplinu klera. O njegovu je radu, koji je nagrađen brojnim crkvenim i državnim priznanjima, Mile Bogović napisao: "Na području školstva i prosvjete učinio je u Senju više nego itko prije i poslije njega. Bio je najveći promotor ideja narodnog preporoda na području svojih biskupija, a dao je i moralnu i materijalnu podršku svim inicijativama usmjerenim na kulturni i gospodarski napredak Hrvatske."16

Iz svega je navedenog razvidno da je biskup Mirko Ožegović bio utjelovljenje vrlina uzornoga svećenika svojega vremena: svim se srcem zalagao za opće dobro hrvatskoga naroda i kao domoljub, i kao mecena, i kao kulturni i prosvjetni djelatnik, i kao čovjek duhovnosti, i kao čovjek temeljitoga obrazovanja (prije teologije završio je pravo i radio u pravničkoj praksi), širokih vidika, visoke nacionalne svijesti, domoljub koji se svesrdno zalagao za očuvanje

\footnotetext{
${ }^{14}$ Usp. M. BOGOVIĆ, 2012, 186.

${ }^{15}$ D. BABIĆ, 1996, 101.

${ }^{16}$ M. BOGOVIĆ, 2012, 187-188.
} 
hrvatskoga nacionalnog identiteta. Jasno je, dakako, i da su osobine biskupa Ožegovića u skladu s navedenim idealima spomenutog Glasnika/Viesnika.

\section{Biskup Ćolić - postojanost u kušnji i život u istini}

U Uvodu smo rada najavili problematiku ovoga članka: svećenikov lik u Posljednjim Stipančićima, tj. fokusiranje na dva lika - biskupa Ćolića i kanonika Vukasovića.

U drugom poglavlju romana Valpurga pripovijeda Luciji o tome kako je sanjala biskupa Ćolića: "Snivala sam da su ga napali nožem Daničići i moji Domazetovići. Sad ja o tome snivam, a kad je to bilo!"17 Biskup Ćolić (punoga imena: Juraj Vuk barun Ćolić de Löwensburg "(...) velik čovjek, učen, pobožan i slavan!"18 umro je, prema Valpurginoj priči, četrdesetak godina prije nego što ona o tome pripovijeda. Iz Valpurgine priče saznajemo da potječe iz obitelji senjskih patricija i plemića te da su ga Senjani jako voljeli i cijenili. O njemu joj je često pripovijedala njezina teta - "druga tetka po ocu, pokojna gospođa Kristina pl. Domazetović". Valpurga ističe Čolićeve kvalitete: "Pa ona mi je sama sto puta pripovijedala kako je na Ćolićeve prodike pomamno letio svijet, to učeno to neuko, to muško to žensko, on da bi znao ljude ganuti do plača. Bio je i sirotinji dobar, a i u obrani pravica našega grada vazda prvi. Naš ga rod nije baš volio, ni Domazetovići, ni djed ti po ocu, jer su Stipančići držali rado s vojničkom vlašću. Ali Ćolića su se bojali. Puk ga je naš najviše zavolio što je gradu sazidao novu crkvicu i u stolnoj crkvi Svete Marije načinio tri nova mramorna oltara i novu krstionicu. I ona lijepa prodikaonica u stolnoj crkvi može se reći da je njegovo djelo. Biskup je Ćolić naime nagovorio bio neku Vugrovićku, ženu iz građanskoga stališa, ali bogatu, te je o svom trošku dala načiniti onu prodikaonicu od samoga mramora." ${ }^{19}$ Dakle, iz Valpurgine je priče razvidno da je Ćolić bio vrstan propovjednik i evangelizator, da je pomagao sirotinji i branio prava svojega grada te da je obogaćivao i sakralnu senjsku baštinu. Ćolić nije bio omiljen ni u Valpurginu ni u Antinu rodu zato što je pripadao drugačijoj političkoj opciji. Domazetovići i Stipančići bili su skloni vojničkoj vlasti, a Ćolić je pak bio njezin protivnik. Valpurga ne zaboravlja spomenuti animozitet koji je vladao između obitelji Ćolić i Domazetović ni mržnju među njima (a ta mržnja nije, nažalost, mimoišla ni biskupa Ćolića): "Ni sam biskup Ćolić, koliko je god mudar i plemenit bio, nije mogao ugušiti u svom srcu tu mržnju, a opet

\footnotetext{
${ }^{17}$ V. NOVAK, 1999, 3.

${ }^{18}$ V. NOVAK, 1999, 54.

${ }^{19}$ V. NOVAK, 1999, 55.
} 
ni Domazetovići, osobito jedan, sad mu se već ne sjećam imena, ne bi propustio ni jednu priliku gdje bi mogao da ugrize biskupa." ${ }^{20}$ Valpurga pripovijeda Luciji kako su Ćolićevi neprijatelji izmislili priču da je Ćolić zaveo lijepu djevojku iz stare plemićke obitelji Homolić. Budući da se glas o tome brzo pronio gradom, Domazetovići, Daničići i Homolići su zbog toga tužili biskupa Ćolića Papi u Rim. Klevetnike je podupirao čak i jedan kanonik, ali spomenuta priča nije bila istinita. Iz Rima je Ćoliću stigla obavijest da mora ravno pred Papu, radi svojega opravdanja. Biskup je Ćolić obavijestio Senjane da će posljednje nedjelje pred odlazak u Rim služiti svečanu misu. Misleći da će na toj misi Ćolić opravdavati sebe i napadati svoje protivnike, cijeli je Senj toga dana došao u crkvu, ali Ćolić čak ni propovijed nije održao. "Ali kad je bilo kod mise na pričest, digne sveto tijelo, okrene se k puku i reče: 'Vi znate, braćo, koliko je protiv mene uspjela ljudska zloba. Bog neka prosti mojim klevetnicima, kao što im ja s ovoga mjesta praštam. A tebi, puče, ispovijedam da sam čist kao što je čist Onaj čije ću tijelo evo blagovati!' Tad je zazvonilo na pričest, a narod je plakao udarajući se u prsa: 'Moj grijeh, moj preveliki grijeh!' Eto, tako ti je to bilo..."21

Biskup Ćolić bio je samosvjestan, siguran u sebe, iskren, nevin i čist. Klevetnicima i onima koji su u klevetu povjerovali i osudili ga oprostio je. Sljedećega je dana otputovao u Rim, a Senjani su planuli na biskupove protivnike (Valpurga kaže da se s prvim mrakom na ulici nisu smjeli pojaviti Domazetovići, Daničići, Homolići). Ćolić se u Rimu sjajno opravdao, a za daljnju se sudbinu oklevetane djevojke ne zna. Nakon svojega opravdanja pred papom Klementom biskup je od njega izmolio kosti raznih mučenika i dao sastaviti tijelo koje nakon što ga je poslao u Senj, počiva u senjskoj stolnoj crkvi (narod je pak mislio da je to sv. Formoz). Ćolić je, dakle, dao sastaviti to tijelo te ga je sa žrtvenikom poslao posebnim brodom iz Rima u Senj. Brod (natovaren solju) nekoga Vukasovića, također Ćolićeva protivnika, istodobno je uplovljavao u senjsku luku. Kad se po Senju razglasilo da iz Rima dolazi brod sa svetim moćima, mnoštvo je svijeta stiglo na obalu da ga dočeka. Svoj je brod među tim svijetom čekao i taj Vukasović koji se htio narugati biskupu Ćoliću pa se obratio mnoštvu naglasivši da njegov brod (brig) nosi sol, a talijanski brod "Ćolićevo kopile". Na kraju te priče o biskupu Ćoliću i njegovim neprijateljima Valpurga je istaknula da je biskupove klevetnike Bog ipak kaznio: "Taj je čas zahvatila morska struja Vukasovićev brig i nanijela ga na hrid gdje se probio i potonuo. I danas se još vidi po tihom vremenu na morskom dnu veliko sidro toga broda, ali nitko ne

${ }^{20} \mathrm{~V}$. NOVAK, 1999, 55.

${ }^{21} \mathrm{~V}$. NOVAK, 1999, 56. 
tiče u nj jer ga ljudi drže Božjim prokletstvom."22 Valpurga u svojoj priči opisuje događaje koji su svjedočili o ljudskoj zavisti, zlobi, nedobronamjernosti, mržnji, podmetanju, tj. o ljudskim slabostima s jedne i o moralnoj i duhovnoj snazi biskupa Ćolića s druge strane. Biskup Ćolić je, dakle, prema Valpurginoj priči, bio meta zavidnika, zlobnika, nedobronamjernika, klevetnika. Obranio je svoju čast, poštenje, dobronamjernost, ostao je miran u kušnji i nevolji, dostojanstven i dostojan svojega poziva. Ta ga kušnja nije pokolebala da oprosti neprijatelju i dalje radi za opće dobro.

Usporedimo li zahtjeve od misnika opisane u Hranićevu članku o Glasniku/ Viesnku iz prve faze njegova izlaženja, pročitat ćemo sljedeće: "Od misnika se traži da bude svet i savršen, ogledalo svake kreposti i uzoritosti. Za svećenike nije dovoljno da poput dobrih i odličnih kršćana svjetovnjaka izbjegavaju grijeh i opačine, nego se moraju truditi oko istinske savršenosti. Nije im dovoljna samo čast njihova zvanja, nego im je potrebna i svetost života. Da bi druge mogli poučavati u kreposti, duhovno ih voditi i Bogu približavati, najprije moraju sami biti duhovni, savršeni i Bogu bliži."23 Stavimo li "Ćolićev slučaj" u navedeni kontekst, zaključit ćemo da je biskup u punom smislu riječi odgovorio zahtjevima svojega poziva. Zlim jezicima i nedobronamjernicima usprkos, biskup je Ćolić sačuvao svoju reputaciju. Vrijednosti koje se pripisuju "Božjemu čovjeku" u opisanome slučaju korespondiraju s vrijednostima koje promiče Glasnik/Vjesnik u svojoj prvoj fazi (naravno, pod pretpostavkom da su te vrijednosti bile aktualne u vrijeme koje prikazuje Novakov roman (vrijeme buđenja ilirizma, dakle tridesetak godina prije početka izlaženja Glasnika/ Viesnika).

\section{Filip Vukasović - domoljub, čuvar tradicije i zagovornik narodnih prava}

Drugi crkveni dostojanstvenik u Novakovu romanu Posljednji Stipančići svećenik je Filip pl. Vukasović. Taj je svećenik "prepošt, arhiđakon i vikar stolne crkve". ${ }^{24}$ Sveznajući nam pripovjedač opisuje Vukasovićev izgled naočita muškarca: "(...) čovjek od četrdeset i pet godina, impozantne vanjštine, visok, neugojen odviše, s mirnim aristokratskim licem i umnim sivim očima." 25

Svećenici su često bili gosti uglednih Senjana (ugošćivanje crkvenih velikodostojanstvenika bio je znak prestiža). Vukasović je bio gost na Jurjevu krštenju, na imendanima Ante Stipančića, dolazio je u Stipančićev dom iza

\footnotetext{
${ }^{22}$ V. NOVAK, 1999, 57.

${ }^{23}$ Đ. HRANIĆ, 1998, 233.

${ }^{24}$ V. NOVAK, 1999, 63.

${ }^{25}$ V. NOVAK, 1999, 63.
} 
svakoga Jurjeva ispita (uz brojne uglednike iz obitelji Domazetović, Homolić, Dragančić, patera Bonaventuru i druge).

Ilirske su ideje u to vrijeme dopirale iz Zagreba i u Senj (a Vukasović ih je svesrdno prihvatio) u kojemu su se odvijale pripreme za budući izbor dvaju zastupnika u Sabor: "Glava pokreta, kanonik Vukasović, bio je uman čovjek, od prirode bogato nadaren, a naukom prosvijetljen, te ne samo porijeklom i imenom nego i duhom svojim pravi narodni aristokrat. On je brzo shvatio pokret što ga je uz grofa Draškovića pripravljao Gaj. Nove vijesti iz Zagreba trgoše mu dušu. Činilo mu se da je već o tom i baš tako i on sam mislio, da je tako šta što su propovijedali Drašković i Gaj smatrao već otprije sam svojom dužnošću, ali kao da nije umio podati jasnoga oblika, vidljivoga života tome što je u njegovoj duši gotovo oživjelo."26

Vukasović je bio prirodno nadaren, pametan, obrazovan, iz ugledne obitelji, produhovljen, napredan, pomno je osluškivao bilo svojega vremena te je prihvatio Draškovićeve i Gajeve ideje. Itekako je bio svjestan pogubnosti tuđinske vlasti i ugašenoga svjetla narodne svijesti: "Živu duhom, učenu, a poletne fantazije, bilo je Vukasoviću da proplače gdjekada nad obijesnom bahatošću tuđe vlasti koja je sputala Hrvate u okove i otimala mu uspomenu na prošlost i na narodno ime. Vidio je da je pogašena luč narodne svijesti, da naraštaj zaboravlja narodni ponos, da je domaći jezik stjeran u neugledne kuće domaćih porodica i u masu naroda koja svojom sudbinom niti može niti umije upravljati; a sav život što se još javlja da nije nego borba za kruh, za čast i vlast." ${ }^{27}$ Usprkos svojemu zanosu i dobroj volji, Vukasović je bio mahom neshvaćen u sredini ograničenih ljudi i njihovih skučenih vidika. Sveznajući pripovjedač spominje da Vukasović žali za Napoleonovim padom (jer je propala ideja "da se obnovi Ilirsko carstvo." ${ }^{28}$ Vukasović je samo još polagao nade u providnost "koja bi spasla ime i život hrvatskomu narodu." ${ }^{29}$ Bio je ogorčen zbog tadašnje situacije u kojoj se našao njegov narod: "Neutješno gledao je pred sobom skoru propast svoga naroda čijom mladom i svježom krvi pomlađuje svoje srce tuđinac."

Vukasović je pomno pratio "zagrebačka" zbivanja, a zagrebački je "osvit" dopro i do Senja. Puno je očekivao od Sabora. Pomno je čitao brošure u kojima su progovarali Kušević, Derkos, grof Janko Drašković. Bio je uvjeren da će Senj prihvatiti ilirsku ideju: "Računajte i s nama, živi smo i mi, ranjeni doduše,

\footnotetext{
${ }^{26}$ V. NOVAK, 1999, 105-106.

${ }^{27}$ V. NOVAK, 1999, 106.

${ }^{28}$ V. NOVAK, 1999, 106.

${ }^{29}$ V. NOVAK, 1999, 106.

${ }^{30}$ V. NOVAK, 1999, 106.
} 
ali živi!"31 U njemu je duboko odjeknula ideja južnoslavenskoga jedinstva: "I čisto je vidio kako s jednakim takovim glasom hrli narod s kranjskih planina, iz ravne Slavonije i Srijema, iz kršne Dalmacije, junačke Crne Gore, tužne Bosne i Hercegovine i smrtno ranjene Srbije - leti k jednomu ognjištu, svi kao sinovi jedne majke šire ruke, u lica se ljube i klikću od radosti što je jednom snagom zahvatila svu ujedinjenu narodnu dušu: našla se eto opet braća na jednom starom domaćem ognjištu! Milijun srdaca zaigralo od te slavne radosti, složne ruke dižu opet stari dom u vlastitoj domaji, što ga za sva već vremena ne može da sruši nijedna ljudska sila. Nametalo mu se od sebe pitanje: tko će od domaćih ljudi u to važno doba znati i htjeti da dostojno zastupa grad u saborima?"32

Vukasović je očito bio idealist; narod ipak nije imao svijesti o stvaranju jedne, ujedinjene duše (s korijenjem u slavnoj prošlosti). Ilirske ideje građani uglavnom nisu razumjeli (niti su za to imali poseban interes): "Izim kojega svećenika u gradu i umirovljenoga majora Ćolića, tko se zanimao za ono što se pripravljalo u Zagrebu!"'33 U Hrvatskoj su tridesetih godina 19. st. patriciji i plemići bili otuđeni od vlastita naroda. Nisu bili dovoljno snažni da se motiviraju mišlju o snazi narodnoga jedinstva i odupiranju tuđinu. Razvijali su ljubav prema tuđemu, a zanemarivali su narodni jezik. Radi osobne koristi težili su biti bliski s vlastima. "Hrvatskom narodu bile su potrgane sve veze po kojima se mogao osjećati potomkom i jednim zakonitim baštinikom slobodnoga i slavnoga nekada kraljevstva hrvatskoga." ${ }^{34} \mathrm{U}$ takvim je uvjetima Vukasović bio idealist, spreman na odricanje i žrtvu, svjestan da u Senju nema dovoljan broj ljudi koji bi podupro ilirsku ideju. Bilo mu je jasno da dijelom naroda vlada bespomoćnost i beznađe, odnarođivanje plemenitaša, rasipanje imovine, gašenje slavne prošlosti otaca. Opće narodno dobro Vukasović je stavio ispred vlastitih interesa. Žao mu je što su neki Senjani povjerovali onima koji su ga optužili kao buntovnika. Svoje sugrađane drži nesamostalnima, nezrelima, nehajnima prema svojoj baštini. Velik dio puka bio je neuk, neprosvijećen, nije razumio ilirske ideje koje im je Vukasović pokušao objasniti (njegove riječi nisu mogle raspaliti srce naroda). Rijetki su ga uistinu razumjeli i podržavali. Ipak, svjestan je da je prosti puk jezgra naroda te da se taj puk budi, da je živ i žilav, da ima onih koji ljube svoj dom i jezik, koji čuvaju i njeguju tradiciju.

Vukasovićevi su protivnici, naravno, imali loše mišljenje o njemu. Ante Stipančić "bio je potpuno uvjeren da je pop Vukasović bio ludi fantast kojega će

\footnotetext{
${ }^{31}$ V. NOVAK, 1999, 107.

${ }^{32}$ V. NOVAK, 1999, 107.

${ }^{33}$ V. NOVAK, 1999, 107.

${ }^{34}$ V. NOVAK, 1999, 108.
} 
mađarski velikaši ismijati u saboru". ${ }^{35}$ Juraj Stipančić Vukasovića karakterizira "usijanim ilircem". Gradski upravitelj, major Benetti, Vukasovića drži idealistom i vječitim nezadovoljnikom, huškačem "nedužnih" ljudi (što rezultira napetošću između građana i vlasti) te je uvjeren da je njegova borba za "pravice" samo maska za pobunu protiv vojničke vlasti i pripojenje Senja civilnom dijelu Hrvatske. Obraćajući se Anti Stipančiću, komentira Vukasovićevo ponašanje: "Zar se ne pojavljuje onamo, kamo teži Vukasović, i druga smiješnost? Zar se ne čuje i glasova: Nećemo ni latinski ni njemački, ni talijanski, ni mađarski; neka se u škole i urede uvede jezik kojim govore hrvatski seljaci! Vjerujete li vi da se u civilnom dijelu Hrvatske, kamo se naklanja Vukasović, čuje i takovih glasova. Uostalom, ja Vukasovića razumijem; inteligentan čovjek koji se usudio otvoreno izjaviti da žali što smo protjerali Francuze, takav čovjek može da zamisli i da prione i uz druge bolesne ideje." ${ }^{136}$ Benetti Vukasovića drži nemirnim duhom, koji je povukao učene, "ozbiljne i trijezne ljude" u "ludo kolo". Ne može shvatiti da je i sudac Ćolić pristao uz Vukasovićeve ideje.

Izborna se borba u Senju razmahala, narod je bio destabiliziran, nezreo, bez čvrstih uvjerenja, nesiguran, malodušan, spreman na kompromise. Neki su ljudi bili neutralni, nikome se nisu htjeli zamjeriti, gledali su samo svoja posla i osobne interese. Jedni su se oduševljavali Vukasovićem, drugi su ga sumnjičili, većina je zapravo bila zbunjena. Neki su vjerovali da su Mađari potkupili grad. Vukasovićeva je pobjeda bila neizvjesna. U narodu su vladale spletke, osobni interesi, nije bilo osjećaja za opće dobro. Vukasović je isticao: "Nema u nas poezije ni ideala, zanosa i vjere u viši duhovni život koji ne ovisi o korici hljeba, ni o pregršti zlata, ni o naslovu, ni o rangu." ${ }^{37}$ Vukasović je bio svjestan činjenice da su Senjani lako potkupljivi, mlitavi, kolebljivi, nesigurni u sebe. Usprkos svemu, nije gubio nadu u budućnost, sretan kad su i malobrojni pokazali volju za opće narodno dobro. Vukasović nije skrivao svoje ambicije te je javno izjavio da se želi kandidirati kao zastupnik u Sabor. I po sposobnostima i po časti imao je velik utjecaj u Senju: "držalo ga se općenito kao najučenijega svećenika u biskupiji." ${ }^{38}$

Dok se još činilo da će se Ante Stipančić uz Vukasovića kandidirati za Sabor, Vukasović je "odlučno zahtijevao da Ante Stipančić u svoj govor uplete i S̆toosove stihove: Vre i svoj jezik zabit Horvati hote, ter drugi narod postati." ${ }^{13}$,

\footnotetext{
${ }^{35}$ V. NOVAK, 1999, 124.

${ }^{36}$ V. NOVAK, 1999, 163-164.

${ }^{37}$ V. NOVAK, 1999, 137.

${ }^{38}$ V. NOVAK, 1999, 157.

${ }^{39}$ V. NOVAK, 1999, 168.
} 
pokazujući tako svoje domoljublje i ljubav prema hrvatskome jeziku. Vukasović je naime želio osvješćivati Hrvate, upozoravati ih na činjenicu da se hrvatski jezik zanemaruje i zaboravlja, a da se Hrvati odnarođuju.

Nakon što je Ante Stipančić odustao od kandidature za drugoga saborskoga zastupnika, Vukasović je za novoga kandidata predložio Josipa pl. Ćolića (koji je na to jedva pristao). Pohvalivši Ćolićev govor, Vukasović je objašnjavao narodu ilirsku ideju - ideju o ujedinjenju južnoslavenskih naroda, spominjao je nedaće koje su ti narodi pretrpjeli pod tuđinskom vlašću i neslogu koja ih je dodatno oslabila. Svjetlo novoga života po njegovu je mišljenju dolazila iz Zagreba, a donosili su ga grof Janko Drašković i dr. Ljudevit Gaj.

Iz opisa i prikaza Vukasovića i njegova djelovanja vidljivo je i jasno da je on čovjek ispred svojega vremena. Plemenita izgleda i podrijetla, obrazovan i nadaren, pun ljubavi prema Bogu i hrvatskom narodu, idealist, ilirac, čovjek širokih vidika u skučenoj sredini. Dunja Merkler ovako će poentirati Vukasovićev lik: "Kanonik Vukasović je utjelovljenje ideala i nacionalnih očekivanja tadašnjega, ilirizmom osviještenoga sloja hrvatskoga puka. Nerealan pristup stvarnosti, uzvišenost i idealizam u štovanju moralnih, nacionalnih i socijalnih principa, dovode do nerazumijevanja njegovih ideja i očitog sukoba uzvišenih ideala i stvarnoga životnoga okruženja u kojemu Vukasović namjerava ostvariti svoje ciljeve." 40

Zaključak: lik svećenika u Posljednjim Stipančićima - moralna vertikala, uzor, domoljub, prosvjetitelj, kulturni radnik i svjetlo na životnome putu

Cilj je ovoga rada bio prikazati lik svećenika u Novakovim Posljednjim Stipančićima. Prikazana su dva lika - biskup Ćolić i kanonik Vukasović. O biskupu Ćoliću saznajemo iz Valpurgina pripovijedanja Luciji; jedan ga je dan sanjala, a onda je taj san potaknuo u njoj sjećanja pa je osjetila potrebu da svojoj kćeri pripovijeda o tom senjskom ugledniku koji je, iz čiste zavisti i zlobe, oklevetan, koji se pred Papom, Bogom i ljudima časno obranio i ostao moralnim pobjednikom. Svoju je priču zaokružila poentom da klevetnike uvijek sustigne zaslužena kazna. Iz Valpurgine je priče razvidno da je biskup Ćolić, pored ostaloga, i kulturni djelatnik (dao je sagraditi crkvicu, a u stolnoj crkvi propovjedaonicu), izvrstan propovjednik, podupiratelj siromaha, borac za pravdu, čovjek visokih moralnih vrijednosti. Očito je zbog svih spomenutih kvaliteta bio metom zavidnika i zlobnika, tj. trn u oku klevetnika koji nisu prezali

${ }^{40}$ D. MERKLER, 1999, 268. 
da ga denunciraju. U narodu se često kaže da munje udaraju u vrhunce planina pa nije čudno što je spomenuti biskup postao metom ljudi "niskih strasti". Da ga omalovaže, ponize, diskreditiraju, zli su jezici izmislili priču o njegovoj vezi s djevojkom plemenita roda, ali biskup se nije dao zbuniti nego se časno obranio i pred narodom i pred papom Klementom i pred Bogom, pokazavši i dokazavši da onome tko živi u istini, nitko ništa ne može. Štoviše, i dalje je radio za opće dobro svojega puka i za njegov rast u vjeri (u Rimu je dao sastaviti kosti mučenika i poslao ih u staklenome lijesu u Senj). Biskup je Ćolić u Valpurginoj priči prikazan kao moralna vertikala senjskoga puka, kao uzor i primjer, dostojan svojega poziva, ponašanja usklađena s postulatima svoje (katoličke) vjere.

Cijenjen i ugledan zbog učenosti i plemenita podrijetla, mudar i obrazovan, kanonik Vukasović većini je Senjana bio moralni i duhovni autoritet, pošten čovjek, pravdoljubiv, istinoljubiv, u skladu sa suvremenim idejama svojega vremena najkorisnijima za opće narodno dobro, domoljub, zagovornik hrvatskoga jezika kao službenoga, čuvar tradicije i nacionalnoga identiteta. Odupirao se nepravdi, ugnjetavanju naroda, nasilju, nametima, otimanju imovine. Bio je svjestan činjenice da se zbog teške ekonomske i društvenopolitičke situacije u narod uvukla malodušnost te da nije bilo istinske narodne sloge, da je narod zbunjen i neodlučan, da se mnogi ni u što nisu htjeli miješati nego su gledali samo osobne interese. Shvatio je pogubnost tuđinske vlasti koja je ugrožavala identitet hrvatskoga naroda, činila Hrvate robovima, zasjenjivala i bacala u zaborav slavnu hrvatsku prošlost, gasila nacionalnu svijest, slamala ponos, obezvrjeđivala hrvatski jezik, poticala kruhoborstvo, častohleplje i vlastohleplje. Zato je bio trn u oku tuđincima koji su upravljali gradom, ali i "domaćim" protivnicima - zavidnicima i zlobnicima, uhljebima i poltronima koji su se dodvoravali vlastima radi osobne koristi. Vukasović je nastojao raditi za opće narodno dobro. Osluškivao je događaje i zbivanja na širem planu, shvatio je i zdušno prenosio ilirske ideje, koje građani mahom nisu razumjeli.

I biskup Ćolić i kanonik Vukasović prikazani su u Novakovu romanu Posljednji Stipančići kao uzori, osobe visokog morala, sjajni dušobrižnici i vrsni predstavnici Crkve. U Valpurginu pripovijedanju o Ćoliću naglašena je njegova borba za istinu, iskreno i istinsko življenje svoje (katoličke) vjere, kulturno djelovanje (gradnja crkava, oltara, poticanje bogatijih žitelja na obnavljanje sakralne baštine), briga za duhovnu dimenziju života Senjana i skrb za opće narodno dobro.

Sveznajući pripovjedač prikazuje kanonika Vukasovića kao čovjeka snažnoga duha i mašte, mudra i učena čovjeka koji je svjestan pogubnosti tuđinske vlasti (porobljuje Hrvate, zatire mu uspomene na nekada slavne dane, utječe 
na slabljenje svijesti o nacionalnom identitetu, obezvrjeđuje hrvatski jezik, tj. marginalizira ga, toliko loše djeluje na narod da on nije u stanju upravljati svojom sudbinom), koji je spreman žrtvovati se za opće dobro, koji poučava i usmjerava puk, koji se bori za narodna prava, koji iskazuje svoje domoljublje zagovorom hrvatskoga jezika kao službenoga, koji nastoji očuvati baštinu i tradiciju svojih predaka te oživjeti sjećanja na nekad slavno hrvatsko kraljevstvo, obnoviti nekadašnji ponos te pobuditi narodnu samosvijest. Podsjetimo se da su se u prvoj fazi izlaženja Glasnika/Vjesnika Đakovačke i Sriemske biskupije promicale sljedeće vrijednosti i svećenikove osobine: svestrano obrazovanje, krepostan, uzoran i svet život, marljivost i postojanost u radu, skrb za narod i kulturnu baštinu. Svećenik je trebao biti čovjek pera i kulture, duboke vjere i duhovnosti, molitelj, pastir svojega naroda i vjerničkoga puka, rodoljub, evangelizator i prosvjetitelj, društveni i politički djelatnik, župni administrator, upravitelj crkvene baštine i promicatelj kulture, shvatit ćemo da se opisane slike svećenika u Posljednjim Stipančićima uklapaju u kontekst duha toga vremena. Podsjetimo li se također prikaza djelovanja biskupa Mirka Ožegovića u stvarnome svijetu, kristalno jasno vidimo da je i njegov rad u skladu s proklamiranim idealima. Likovi svećenika u mogućem (Ćolić i Vukasović iz Posljednjih Stipančića) u harmoniji su sa slikom idealnog svećenika iz Glasnika/Viesnika i Ožegovićevim djelovanjem u stvarnome svijetu.

Ovim smo člankom istražili tek kap u moru blaga o svećenikovu liku u hrvatskoj književnosti. Korpus te književnosti nudi ogroman prostor za daljnja istraživanja.

\section{Literatura}

I. Izvor

Vjenceslav NOVAK, Posljednji Stipančići, U glib, ABC naklada, Zagreb, 1999.

\section{Knjige i članci}

Dragomir BABIĆ, Rodni grad Senj kao izazov Vjenceslavu Novaku, Riječ. Časopis za filologiju, 2, Hrvatsko filološko društvo, Rijeka, 1996, 99-106.

Antun BARAC, Vjenceslav Novak, u: Mate UJEVIĆ (ur.), Plodovi srca i uma. Hrvatska čitanka za više razrede srednjih škola, Treći dio. Hrvatska književnost od Narodnog preporoda do danas, Nakladni odjel Hrvatske državne tiskare, Zagreb, 1941, 272-274. 
Romana BENIĆ BRZICA, Lik svećenika u suvremenom romanu (Meša Selimović: Derviš i smrt, Jiři Šotola: Družba Isusova), Magistarski rad, Filozofski fakultet Sveučilišta u Zagrebu, Zagreb, 2008.

Romana BENIĆ BRZICA, Prikazivanja lika svećenika u književnosti hrvatskoga $i$ slovenskoga modernizma. Doktorska disertacija, Filozofski fakultet Sveučilišta u Zagrebu, Zagreb, 2019.

Mile BOGOVIĆ, Crkva i senjsko srednje školstvo, Senjski zbornik, 36, Senj, 2009, 5156.

Mile BOGOVIĆ, Senjski biskup Mirko Ožegović (1833.-1869.), Cris, 1, Križevci, 2012, 183-188.

Đuro HRANIĆ, Lik svećenika u Glasniku/Vjesniku Đakovačke i Srijemske biskupije, Diakovensia, 6, Đakovo, 1998, 227-256.

Dubravko JELČIĆ, Povijest hrvatske književnosti, Naklada Pavičić, Zagreb, 1997.

Dunja MERKLER, Predgovor, u: Vjenceslav Novak, Posljednji Stipančići, U glib, ABC naklada, Zagreb, 1999, 5-35.

Dunja MERKLER, Metodička obrada, u: Vjenceslav Novak, Posljednji Stipančići, $U$ glib, ABC naklada, Zagreb, 1999, 263-278.

Krešimir NEMEC, Povijest hrvatskog romana od početaka do kraja 19. stoljeća, Znanje, Zagreb, 1995.

Slobodan PROSPEROV NOVAK, Povijest hrvatske književnosti. Između Pešte, Beča i Beograda, Svezak II, Marjan tisak, Split, 2004.

Milivoj SOLAR, Književni leksikon. Pisci. Djela. Pojmovi, Matica hrvatska, Zagreb, 2011.

Miroslav ŠICEL, Pregled novije hrvatske književnosti, Matica hrvatska, Zagreb, 1971.

Stipe TADIĆ, Službenici svetoga. Prilog fenomenologiji svećeničkog zvanja, Školske novine, Zagreb, 1993. 


\section{THE CHARACTERS OF THE PRIESTS IN THE NOVEL THE LAST STIPANČIĆS BY VJENCESLAV NOVAK}

\section{Summary}

A priest's persona is an interesting theme in both everyday life and literary work. It is not easy to be a priest because they are under the great magnifying glass of believers and nonbelievers, benefactors and evil people, dignitaries as well as common people. Every time certain demands are placed before a priest. Some people are well-meaning critics and evaluators of the work of the "servant of God", whilst others can hardly wait for their mistakes to belittle them. Although the characters of priests (although not as the leading ones) appear in Novak's novel The Last Stipančićs (1899), they have not been written about in detail. This is why we want to explore the mentioned theme. We will analyse the characters of two priests: the character of Bishop Ćolić and the character of Canon Vukasović in the mentioned novel.

Bishop Ćolić first appears in Valpurga's dream, which wakens her memories of that Senj dignitary and motivates her to tell Lucija about an episode from the bishop's life when evildoers and envious people slandered and accused him of seducing a girl from a respectable family. Valpurga points out that the mentioned bishop successfully justified himself before Pope Clement and so preserved his honour, reputation and dignity, and remained an exemplary preacher, clergyman, moral authority and fighter for justice and truth. Moreover, he forgave his slanderers and so expressed love for his enemy. In Valpurga's storytelling about Ćolić his struggle for the truth is emphasised, the sincere and true way of living his (Catholic) faith, cultural activities (building churches, altars, encouraging wealthier people to restore sacral heritage), caring for the spiritual dimension of the life of the people of Senj and caring for the general public good.

Canon Vukasović is also portrayed in a positive light - as a man from a respectable family, learned and wise, a true patriot, a fighter for the Croatian language, a defender and guardian of national identity, a man willing to sacrifice for the common good. The all-knowing narrator portrays Canon Vukasović as a man of strong spirit and imagination, a learned man who is aware of the pitfalls of foreign rule (which enslaves Croats, erases his memories of former glorious days, impacts the weakening of the awareness of Croatian identity, devalues the Croatian language, i.e. marginalises it, it acts so badly on the people that it is on no condition to control its own destiny), who teaches and guides the people, who fights for people's rights, who expresses his patriotism by advocating for the Croatian language as the official language, who strives to preserve the heritage and tradition of his ancestors and to revive the memories of the once glorious Croatian kingdom, to renew the former pride and to awaken the people's self-awareness. Such an image of a priest fits into the temporal context of the novel as well as in the spirit of that time, for example in the ideals of the priests proclaimed in the first phase of the Glasnik/Viesnik Đakovačke i Sriemske biskupije (which were supposed to have been valid throughout the region of Croatia) as well as in the actual activities of Bishop Mirko Ožegović in Senj of Novak’s time.

Both Bishop Ćolić and Canon Vukasović are presented in Novak's novel The Last Stipančićs as role models, morally upstanding, people with wide horizons. With this article, we have investigated just a drop in the ocean of treasures about the characters of priests in Croatian literature. Aware that the corpus of Croatian literature offers a huge space for further research on the touched upon subject we want to open the door slightly to new works.

Keywords: a priest, Bishop Ćolić, Canon Vukasović, morally upstanding role models, patriots 